\title{
Reconstruction of sediment supply from mass accumulation rates in the Northern Adriatic Basin (Italy) over the past 19,000 years
}

\author{
Marit B. Brommer, ${ }^{1,2}$ Gert Jan Weltje, ${ }^{1}$ and Fabio Trincardi ${ }^{3}$ \\ Received 19 January 2008; revised 23 September 2008; accepted 8 December 2008; published 23 April 2009.
}

[1] Reconstruction of sediment supply is hampered by the incompleteness of the stratigraphic record. This problem may be partly circumvented by studying mass accumulation rates in closed systems, i.e., basins in which no sediment has bypassed the site of deposition over the time interval of interest. We present time-averaged basin-wide mass accumulation rates and their associated uncertainties from a well-documented closed basin, the Northern Adriatic Basin (Italy), spanning the time interval from $19 \mathrm{ka}$ B.P. to the present. The sediment masses of five basin-wide lithosomes and their associated uncertainties are derived by means of stochastic simulation, using highresolution seismic data, porosity profiles, and radiocarbon datings. This study demonstrates that inferring rates of sediment supply from conformity-bounded stratigraphic units is feasible, as indicated by the excellent agreement of our results of mass accumulation over the past 400 years with two independently derived estimates. Formation of the stratigraphic record is not an instantaneous process. By comparing spatial patterns of mass accumulation rates on three different timescales (decadal, centennial, and millennial) we demonstrate a low preservation potential of sediments presently accumulating near the coast, and a continuous cross-shore and alongshore sediment transport regime. The change from transient to persistent accumulation patterns in the highstand systems tract of the Northern Adriatic Basin occurs at the centennial to millennial timescale. Intrabasinal erosion and recycling of sediments obscure the relation between rates of sediment supply and net basin-wide mass accumulation, which limits the amount of information that can be extracted from the stratigraphic record. Hence, a mismatch between rates of sediment supply and accumulation rates is expected for unconformity-bounded sequence-stratigraphic units. Given the uncertainties associated with our estimates, we are unable to reject the hypothesis that net basin-wide mass accumulation rates have been constant over the time interval of 19,000 years (at a 10\% significance level).

Citation: Brommer, M. B., G. J. Weltje, and F. Trincardi (2009), Reconstruction of sediment supply from mass accumulation rates in the Northern Adriatic Basin (Italy) over the past 19,000 years, J. Geophys. Res., 114, F02008, doi:10.1029/2008JF000987.

\section{Introduction}

[2] The recent trend in the Earth science community to consider Earth surface processes within a holistic ("sourceto-sink") framework has been motivated by the prospect of providing new insights into the responses of our planet to (anthropogenic) environmental perturbations. This development is exemplified by the Community Surface Dynamics Modeling System (CSDMS; http://csdms.colorado.edu), which is aimed at developing, supporting and disseminating integrated software modules that predict the erosion, transport, and deposition of sediment and solutes in landscapes

\footnotetext{
${ }^{1}$ Department of Geotechnology, Delft University of Technology, Delft, Netherlands.

${ }^{2}$ Now at Royal Haskoning, Peterborough, UK.

${ }^{3}$ Istituto per la Geologia Marina, CNR-ISMAR, Bologne, Italy.

Copyright 2009 by the American Geophysical Union. 0148-0227/09/2008JF000987\$09.00
}

and sedimentary basins. The aim to systematically address problems of Earth surface dynamics raises pertinent questions about the extent to which geological data sets are capable of providing benchmarks for such integrated models. In this contribution, we will focus on a topic that has received comparatively little attention in the Earth science community: the derivation of long-term sediment budgets from the stratigraphic record. The importance of such studies is that they potentially allow Earth scientists to incorporate a fundamental law of physics in data-model comparisons, i.e., conservation of mass.

[3] The natural unit in the "source-to-sink" view of Earth surface dynamics is the sediment dispersal system, which comprises an erosional basin in which sediments are generated (the source) and a sedimentary basin in which they are deposited (the sink). Knowledge of rates of mass transfer from source to basin on geological timescales forms an essential link between stratigraphic and geomorphologic modeling [Leeder, 1997; Weltje et al., 1998; Paola and 


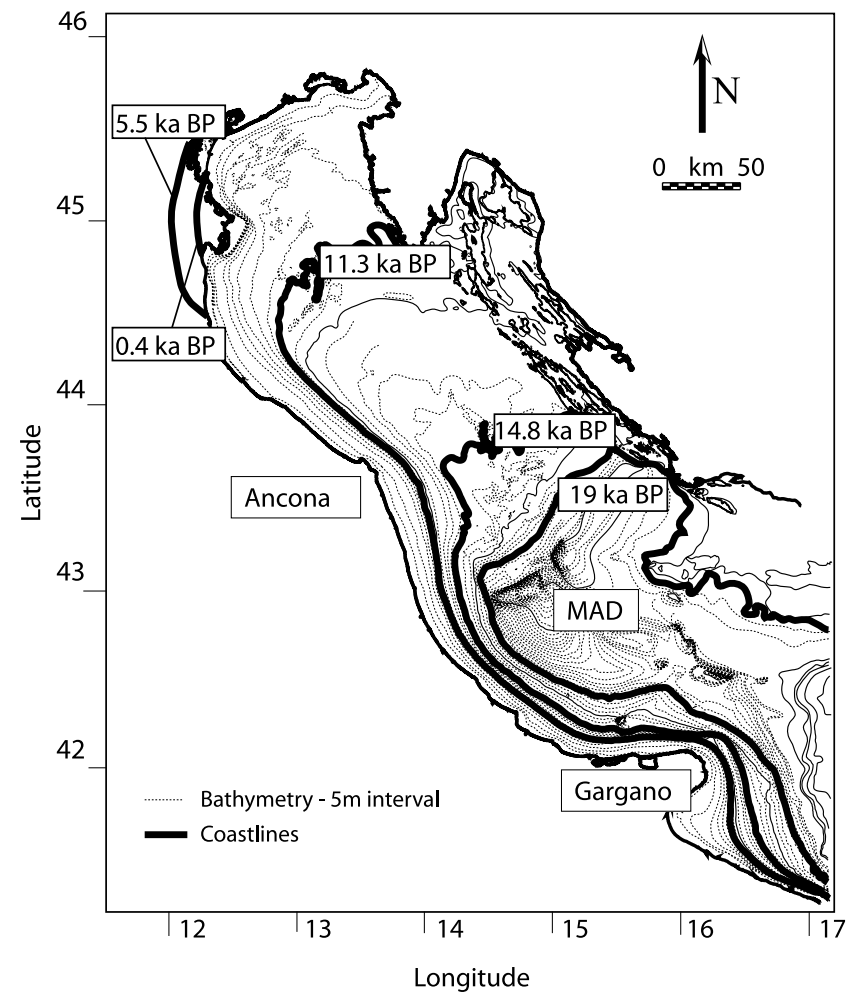

Figure 1. The Northern Adriatic Basin, Italy.

Swenson, 1998]. The frequency bands in which variations of sediment supply are widely believed to be concentrated range from $10^{3}$ to $10^{5}$ years [Hovius and Leeder, 1998]. In the Quaternary, this timescale coincides with glacio-eustatic cycles, which profoundly affected drainage basin evolution and governed basin-fill architecture through high-amplitude sea level changes. Since the Last Glacial Maximum (LGM, $\sim 21$ ka B.P.), fluvial sediment fluxes have varied significantly [Blum and Törnqvist, 2000; Walling, 2006], and deglaciation following the LGM has led to an acceleration of erosion in glaciated catchment areas [Hallet et al., 1996; Molnar and England, 1990].

[4] Reconstructing sediment supply from the stratigraphic record is not a straightforward task, which explains the limited knowledge on rates of sediment supply to basins on geological timescales [Hovius and Leeder, 1998]. One of the fundamental problems in reconstructing sediment supply is the incompleteness of the stratigraphic record [Sadler, 1981; Sommerfield, 2006; Jerolmack and Sadler, 2007], which reflects the limited preservation potential of continental margin deposits. Therefore, sediment dispersal systems that are the most likely candidates for successful reconstructions of palaeo-sediment fluxes are the so-called "closed" basins, i.e., those in which no sediments have bypassed the site of deposition (over the time interval of interest). However, even in "closed" basins, direct calculation of longterm mass accumulation rates from the stratigraphic record is only valid if the quantity of sediment subjected to intrabasinal erosion and recycling is insignificant relative to the amount of sediment supplied to the basin [Einsele and Hinderer, 1998]. Another requirement for such studies is the accurate and precise age estimation of (presumably) isochronous key surfaces of basin-wide extent [Lowe et al.,
2007]. If all of these conditions are fulfilled, calculation of basin-wide sediment accumulation rates on geological timescales would constitute the first step toward the development of generic methods to reconstruct sediment supply from the stratigraphic record.

[5] In this paper, we present time-averaged mass accumulation rates and their associated uncertainties within a well-documented closed basin, the Northern Adriatic Sea (Italy) spanning the time interval from 19 ka B.P. to the present. Quantification of the uncertainties of our estimates is required to compare mass accumulation rates across a series of time intervals, in order to decide whether basinwide changes in time-averaged rates of sediment supply can be inferred from the stratigraphic record. We derive the sediment masses of five lithosomes and their associated uncertainties by means of stochastic simulation, since the nature of stratigraphic data does not permit the use of simple analytical rules of error propagation. Our approach is based on standard procedures employed in the oil and gas industry to analyze the hydrocarbon content of reservoirs (commonly referred to as "Stock Tank Oil Initially In Place" (STOIIP) or "Gas Initially In Place" (GIIP)). Basic requirements to accurately derive the value of the STOIIP/GIIP are, among others, estimation of the bulk volume of the rock containing oil or gas, as well as the porosity of the rock, which determines the total pore volume available for storage of hydrocarbons [White and Gehman, 1979; Agarwal et al., 1999 , and references therein]. Our aim is to estimate the complement of pore volume: the sediment volume, which can be converted to mass for the purpose of obtaining basinwide accumulation rates.

[6] The stochastic simulation used to derive the timeaveraged mass accumulation rates and their uncertainties are described in the first part of this paper. The second part of the paper consists of the interpretation and discussion of the results.

\section{Study Area}

\subsection{Adriatic Basin}

[7] The Northern Adriatic shelf (Figure 1) is shallow and has a low gradient of approximately $0.05^{\circ}$ [Trincardi et al., 1994]. Sediment input is restricted to the Northern and Western side of the basin [Cattaneo et al., 2003]. The MidAdriatic Deep (MAD), a depression in the center of the Adriatic, acted as a sediment trap since the Last Glacial Maximum (LGM), which allows us to regard the Adriatic Basin as a closed sedimentary system [Cattaneo et al., 2003; Ridente and Trincardi, 2005]. After the LGM, sea level rose and the areal extent of the basin increased, which caused a counterclockwise longshore current to become active at around $14 \mathrm{ka}$ B.P. [Cattaneo and Trincardi, 1999]. From that time on, fine-grained sediment dispersed to the Adriatic Sea by Alpine and Apennine Rivers was conveyed to the Southwest to form an elongate shoreparallel prodelta, which extends to the area south of the Gargano peninsula.

\subsection{Northern Adriatic Shelf}

[8] The transgressive and highstand deposits at the Northern Adriatic shelf have been mapped in great detail on the basis of high-resolution 2-D seismic data $(>40.000 \mathrm{~km}$ of 

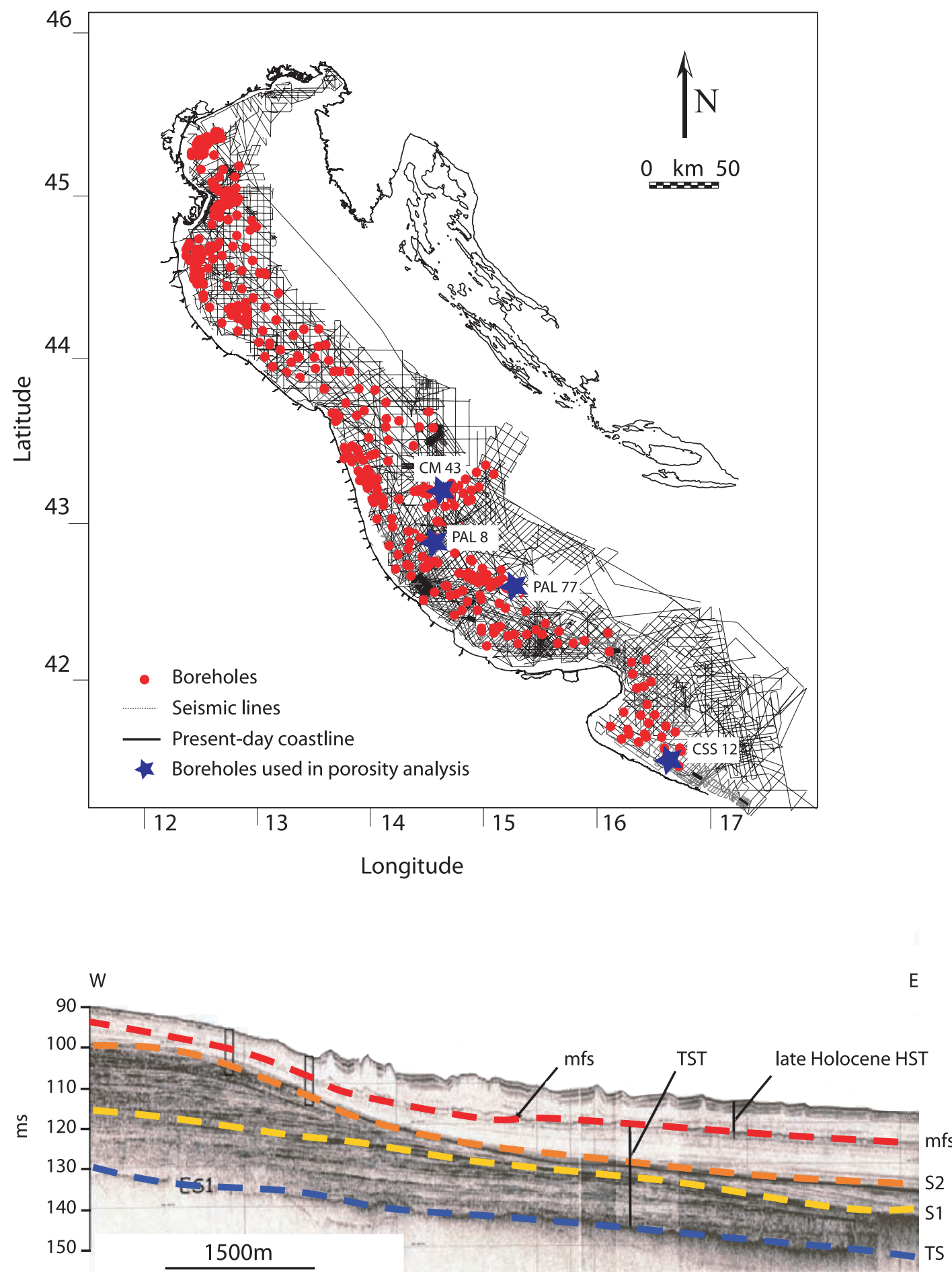

Figure 2. Example of the Adriatic seismic-stratigraphic record (Chirp Sonar profile AMC 182; modified from Cattaneo and Trincardi [1999]). The maximum flooding surface (MFS) separates the highstand systems tract (HST) from the underlying transgressive systems tract (TST). The TST has been subdivided into three units (TST-1, TST-2, and TST-3) by two unconformable surfaces (S1 and S2). The lower boundary of the TST is formed by the maximum regressive surface, which at most localities has been crosscut by a transgressive surface.

CHIRP-sonar and $3.5 \mathrm{kHz}$ subbottom profiles), supplemented by analyses of a large number of sediment cores [Trincardi et al., 1994; Cattaneo and Trincardi, 1999; Correggiari et al., 2001; Cattaneo et al., 2003]. Figure 2 provides an overview of the seismic lines and borehole data and presents a selected example of the seismic-stratigraphic record of the Adriatic Basin. Additional data can be retrieved from a public database stored online at www.pangea.de 

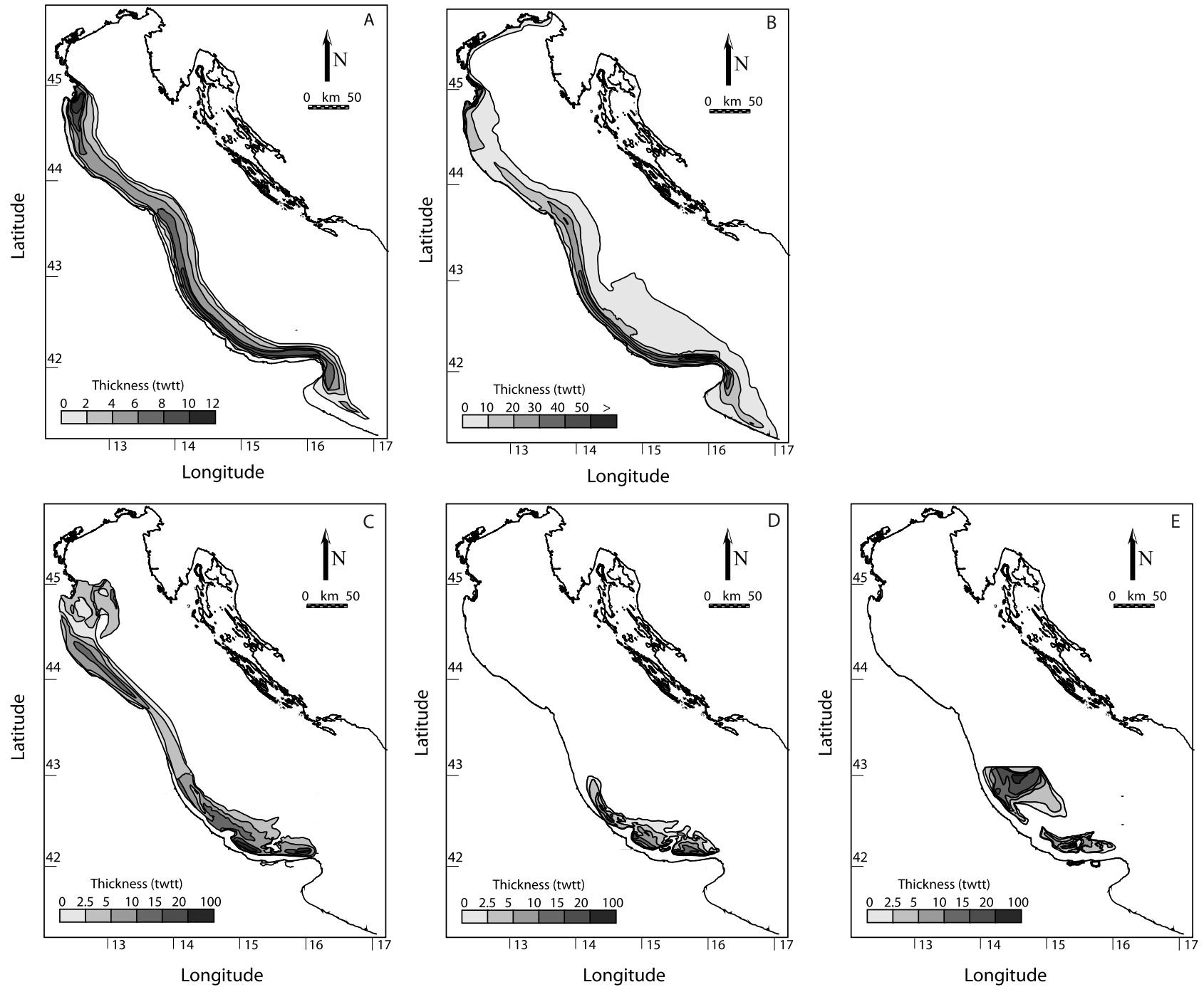

Figure 3. Two-way traveltime maps (ms) of lithosomes at the Adriatic shelf showing (a) HST-2, (b) HST-1, (c) TST-3, (d) TST-2, and (e) TST-1.

which contains geoscientific and environmental metadata acquired during several EU-funded projects (EuroStrataform and Eurodelta).

[9] Four basin-wide stratigraphic surfaces have been recognized, whose ages were established by ${ }^{14} \mathrm{C}$ dating [Trincardi et al., 1994; Correggiari et al., 2001; Cattaneo et al., 2003; Asioli et al., 2001]. Correggiari et al. [2001] subdivided the Highstand Systems Tract (HST) into an upper unit (HST-2; 0.4-0 ka B.P.) and a lower unit (HST-1: 5.50.4 ka B.P.). These two units are bounded by conformable surfaces, the lowermost of which represents the maximum flooding surface (MFS). The three lithosomes comprising the Transgressive Systems Tract (TST), which contain the record of abrupt deglacial sea level rise, are the upper unit (TST-3; 11.3-5.5 ka B.P.), the middle unit (TST-2; 14.8$11.3 \mathrm{ka}$ B.P.), and the lower unit (TST-1; 19.0-14.8 ka B.P.) [Cattaneo and Trincardi, 1999]. These units are separated by unconformable ravinement surfaces (S1 and S2 (Figure 2)), which the exception of the TST-1 unit, which is bounded locally by the maximum regressive surface (MRS) in places where this surface has not been cut by the lowermost ravinement surface (TS) (Figure 2) [Trincardi et al., 1994]. Twoway traveltime maps (ms) have been constructed for each of these five seismic-stratigraphic lithosomes (Figures 3a, 3b, $3 \mathrm{c}, 3 \mathrm{~d}$, and $3 \mathrm{e})$.

\subsection{Po Delta}

[10] The transgressive record of the Po Plain was compiled from published stratigraphic data (Figure 4) [Amorosi et al., 1999, 2003, 2005; Amorosi and Milli, 2001; Farabegoli et al., 2004; Stefani and Vincenzi, 2005]. The transgressive wedge in the Po plain has a maximum thickness of $15 \mathrm{~m}$, and is attributed to the uppermost TST unit (TST-3). The coastline at the time of maximum flooding (5.5 ka B.P.) was located $50 \mathrm{~km}$ inland of the present coastline (Figure 1) [Correggiari et al., 2001]. The MFS is located at a depth of $29 \mathrm{~m}$ below the surface of the modern Po Delta [Correggiari et al., 2005; Stefani and Vincenzi, 2005], which is consistent with long-term subsidence rates of the Po plain [Carminati and Martinelli, 2002]. The highstand deposits are on aver- 

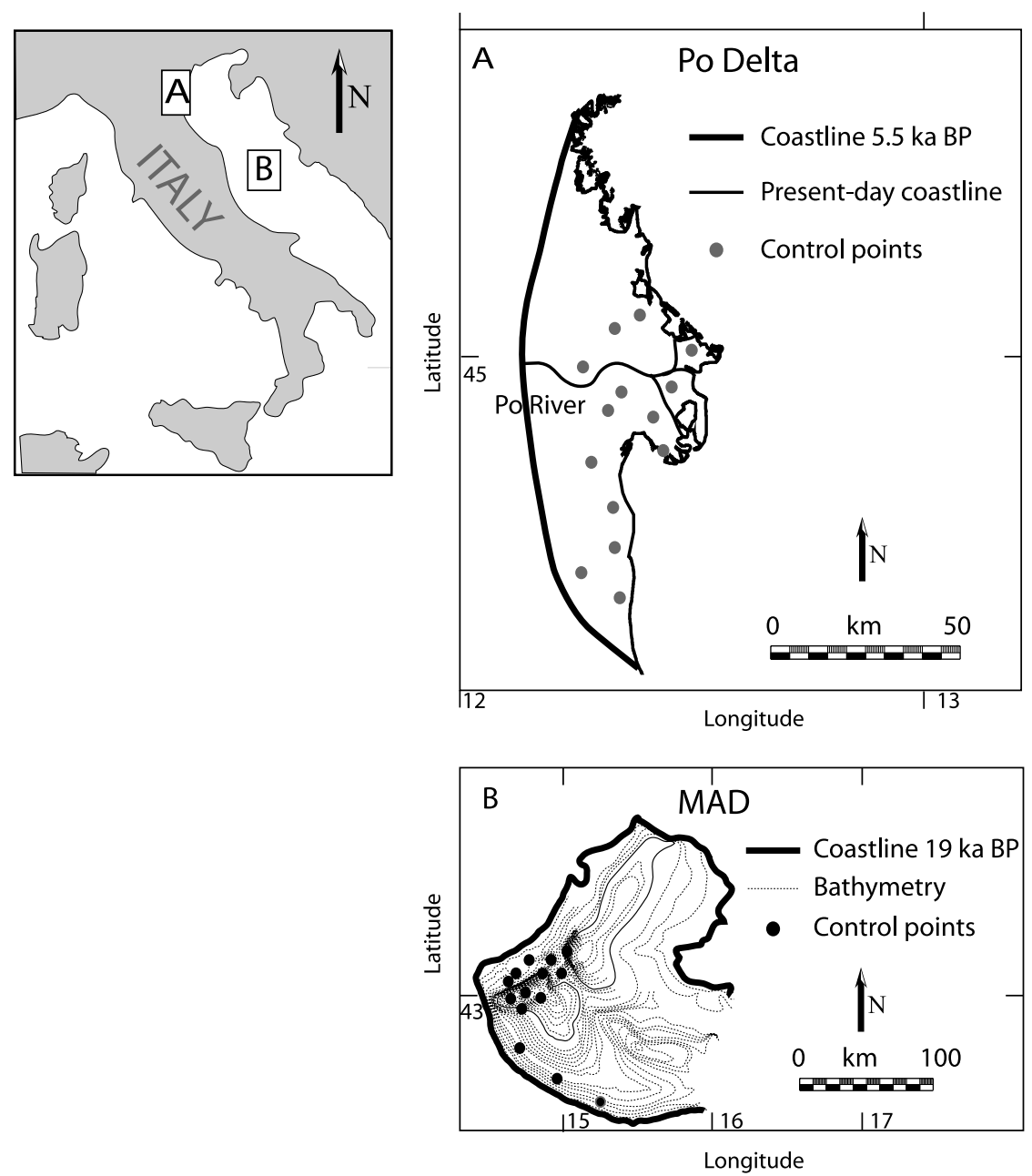

Figure 4. Detailed overview of the (a) Po Delta and the (b) Mid-Adriatic Deep with control points used to derive isopach maps.

age $12-15 \mathrm{~m}$ thick. The onshore part of the HST was subdivided into a lower and upper unit, in accordance with the offshore deposits.

\subsection{Mid-Adriatic Deep}

[11] The thicknesses of the TST and HST units within the MAD were derived from published data on sediment accumulation rates from several sediment cores (Figure 4) [Trincardi et al., 1996; Asioli, 1996; Langone et al., 1996; Alvisi and Frignani, 1996]. These data were interpolated in order to construct surfaces for the TST- 2 and TST- 3 units. The TST- 3 and HST- 1 units in the MAD have been mapped from seismic profiles.

\section{Stochastic Analysis of the Stratigraphic Record 3.1. Geostatistical Modeling}

[12] The analysis started with digitization of the contour lines of the five hand-drawn two-way traveltime maps of the Adriatic shelf lithosomes (Figures 3a, 3b, 3c, 3d, and 3e). The result of this operation was a series of $(x, y, t)$ vectors wherein $x$ and $y$ are the spatial coordinates (latitude, longitude) and $t$ represents two-way traveltime (ms) of the seismic signal. Equally spaced grids with 3 by $3 \mathrm{~km}$ grid cells were produced by geostatistical interpolation (ordinary kriging) of irregularly spaced control points. Geostatistical interpolation was preceded by the following transformation of $t$ :

$$
\tilde{t}=\log (t+\varepsilon)
$$

where $\varepsilon$ is a small positive constant $\left(\varepsilon=10^{-6}(\mathrm{~ms})\right)$. The interpolated $\tilde{t}$ values were subjected to an inverse transform that prevents the occurrence of negative traveltimes:

$$
t=\left\{\begin{array}{cll}
\exp (\tilde{t})-\varepsilon & \text { if } & \exp (\tilde{t})>\varepsilon \\
0 & \text { if } & \exp (\tilde{t}) \leq \varepsilon
\end{array}\right.
$$

[13] The semivariogram required for geostatistical interpolation cannot be estimated from the discrete $\tilde{t}$ values corresponding to the contour lines of the digitized data. To avoid the bias related to input points being aligned along contour lines [Favalli and Pareschi, 2004], we constructed hypothetical measurements by connecting each data point with its nearest neighbor on an adjacent contour line. The $\tilde{t}$ value corresponding to a randomly chosen point $(x, y)$ on each constructed line was estimated by means of linear 

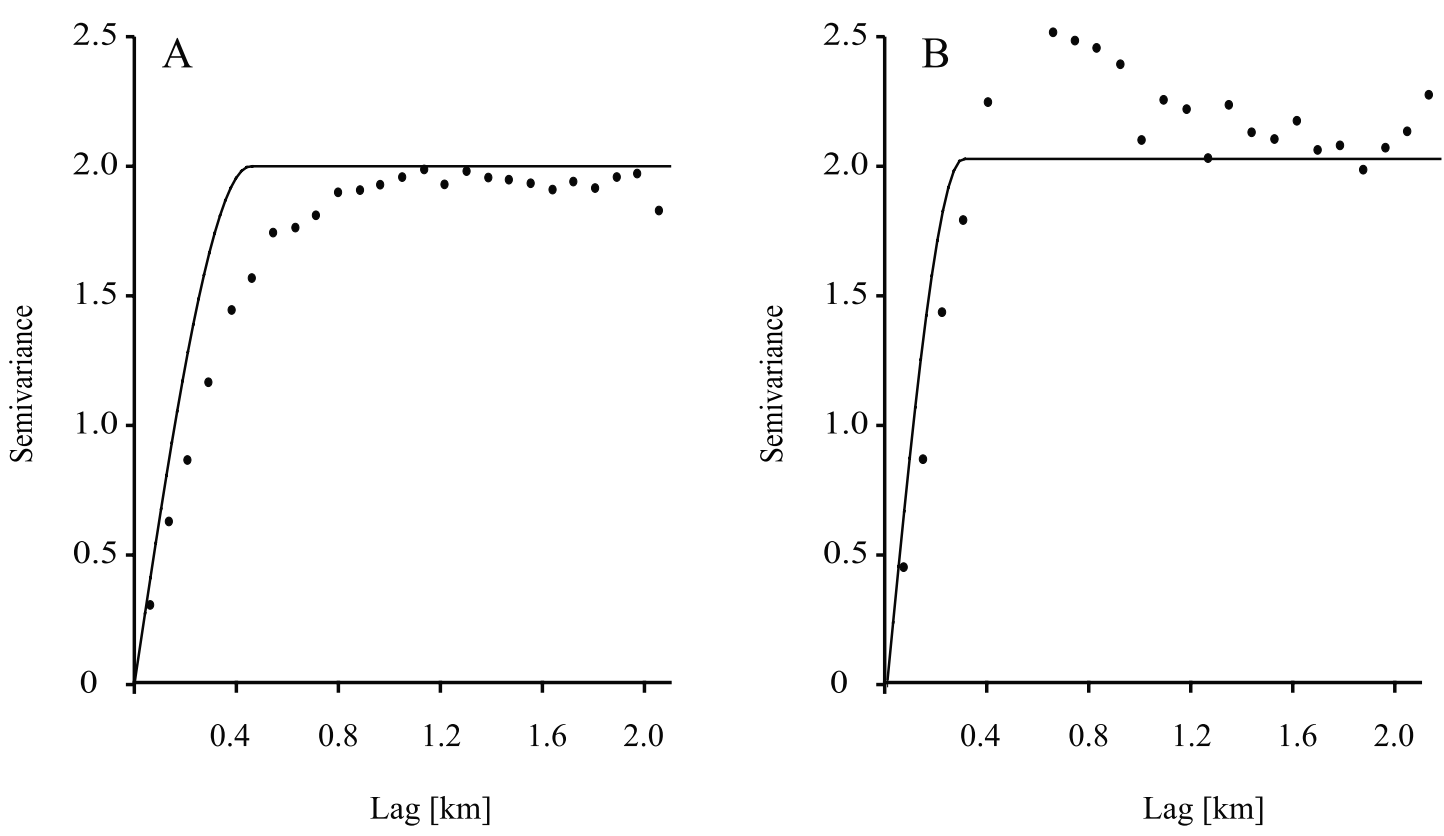

Figure 5. Anisotropic semivariogram model illustrated for HST-1 lithosome. (a) Shore parallel and (b) shore normal.

interpolation of the two bounding $\tilde{t}$ values. We fitted spherical semivariogram models to these hypothetical data points for each lithosome separately. Figure 5 illustrates the semivariogram model of the HST-1 unit. It captures the difference in lateral continuity parallel (NW-SE: $145^{\circ}$ ) and perpendicular $\left(\mathrm{NE}-\mathrm{SW}: 045^{\circ}\right)$ to the shoreline by means of an anisotropy ratio of 2.0 for the range.

[14] The two-way traveltime maps of the five lithosomes are based on a large number of seismic lines and sediment cores. However, the fact that we do not know how many measurements were used to construct these maps, nor the exact locations of the control points, introduces a sampling error. We assessed the magnitude of this uncertainty associated with the finite number of control points by random sampling of control points from each lithosome. We constructed 100 subsets of 100, 300, 600 and 1000 control points each, and used these to examine the relation between the number of control points and the variance of the estimated sediment mass (full mass calculation given below). Figure 6 illustrates the result of this exercise for the HST-1 lithosome. The uncertainty of the estimated sediment mass is clearly influenced by sampling error if the number of randomly selected control points is less than 600. Beyond 600 control points, however, the standard deviations of sediment mass estimates become constant. On the basis of these and similar experiments with the other lithosomes, the number of control points was set to 1000 .

\subsection{Time-Depth Conversion}

[15] A velocity-depth model is required for time-depth conversion of reflectors. We assumed that velocity does not differ significantly with depth, in view of the shallow nature of the deposits and their limited thickness. The velocity of a (seismic) wave through seawater $\left(1500 \mathrm{~m} \mathrm{~s}^{-1}\right)$ is often taken to be applicable to shallow marine deposits as well [Trincardi et al., 1994; Bertrand and MacBeth, 2003].
However, some authors propose a velocity of 1550 to $1600 \mathrm{~m} \mathrm{~s}^{-1}$ [Park et al., 2000; T. Missiaen, personal communication, 2006]. In our stochastic simulation, we used a normally distributed velocity of $1550 \pm 15 \mathrm{~m} \mathrm{~s}^{-1}$ (mean \pm standard deviation), to ensure that the velocity falls between 1500 and $1600 \mathrm{~m} \mathrm{~s}^{-1}$ (Table 1). Time-thickness conversion of seismostratigraphic units was performed as follows:

$$
d_{i}=z_{T}-z_{B}=V_{s}\left(t_{B}-t_{T}\right)
$$

where $d_{i}$ is the estimated lithosome thickness of the $i$ th gridcell $(\mathrm{m}), z$ is depth below the surface $(\mathrm{m}), V_{s}$ is seismic velocity $\left(\mathrm{m} \mathrm{ms}^{-1}\right)$ and $t$ is two-way traveltime (ms). Subscripts $T$ and $B$ refer to the top and bottom of the lithosome.

\subsection{Sediment Mass Calculation}

[16] Conversion of sediment volume to mass requires a careful estimate of the porosity profile of each lithosome.

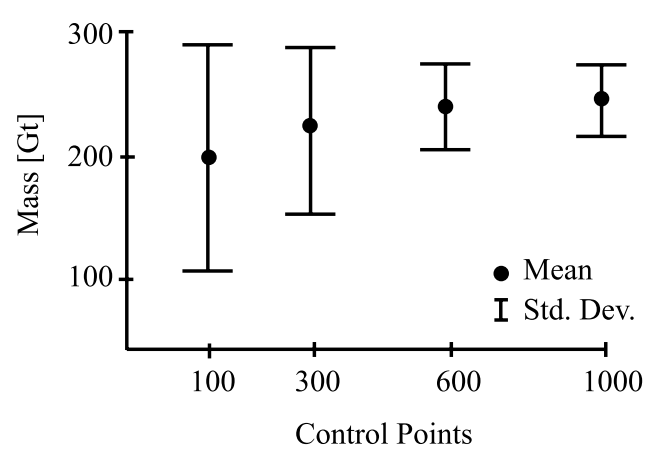

Figure 6. Mean and standard deviations of sediment mass (each estimate based on 10,000 realizations) for differentsized subsets, illustrated for HST-1 lithosome. 
Table 1. Parameters of Shelf, MAD, and Po Delta Deposits Used in Stochastic Time-Depth Conversion

\begin{tabular}{lccccc}
\hline & \multicolumn{2}{c}{ Shelf and MAD } & & \multicolumn{2}{c}{ Delta } \\
\cline { 2 - 3 } \cline { 5 - 6 } Parameter & $\mu$ & $\sigma$ & & $\mu$ & $\sigma$ \\
\hline$\phi_{0}{ }^{\mathrm{a}}$ & 0.35 & 0.03 & & 0.25 & 0.02 \\
$c^{\mathrm{a}}$ & 0.22 & 0.03 & & 0.22 & 0.03 \\
$\phi_{b}{ }^{\mathrm{a}}$ & 0.35 & - & 0.25 & - \\
$V_{s}\left(\mathrm{~m} \mathrm{~s}^{-1}\right)$ & 1550 & 15 & - & - \\
\hline
\end{tabular}

${ }^{\mathrm{a}}$ Nondimensional.

Core data and surface samples [Asioli, 1996; Langone et al., 1996; Trincardi et al., 1996; Asioli et al., 2001; Frignani et al., 2005] indicate an average near-surface porosity of 0.65 to 0.80 and a consistent down core decrease to about 0.35 . Investigation of marine sediments with burial depths up to $1 \mathrm{~km}$, mostly in drill cores from the Deep Sea Drilling Project (DSDP) and Ocean Drilling Program (ODP), show that different porosity-depth relationships (exponential, linear) may apply for different types of sediments in specific geological settings [e.g., Bayer and Wetzel, 1989; Bruckmann, 1989; Huang and Gradstein, 1990]. Bartetzko and Kopf [2007] investigated the upper 50m of 168 ODP sites in order to derive porosity-depth relationships, and found that for a small number of sites an exponential equation gives a higher correlation coefficient than a linear porosity-depth equation. For the majority of the sites, the difference in correlation for linear and exponential porositydepth relationships is relatively small.

[17] An exponential relationship implies that the largest change in porosity takes place in the uppermost meters of the sediment column (i.e., shallow burial depth), which is often the case in shallow marine environments as opposed to deeper waters [Bartetzko and Kopf, 2007]. The reason for this abrupt change in the uppermost meters of the sediment column is the presence of an active sediment-water interface. Beyond $5 \mathrm{~m}$ burial depth, a more or less linear porosity-depth relationship is found which gradually becomes constant at depths $>30-50 \mathrm{~m}$. At even greater burial depths of several kilometers, this linear behavior gives way to an exponential function, reflecting the asymptotic approach of porosity values to a lithology-specific minimum.

[18] The exponential porosity-depth equation proposed by Athy [1930] forms the conceptual basis of most algorithms used today. Examples of the use of Athy's [1930] porosity-depth equation in various geological settings are discussed in detail by Giles [1996], whereas Bahr et al. [2001] provided a physical interpretation of its parameters. Athy's [1930] exponential porosity-depth equation is based on measurements at $>500 \mathrm{~m}$ burial depth, which is beyond the depth range of (sub)recent sedimentary environments $(0-500 \mathrm{~m})$. However, the similarity between very shallow (several meters) and very deep (several kilometers) porosity profiles suggests that Athy's [1930] porosity-depth equation may also be used to capture the decreasing rate of porosity reduction with depth in the shallow muddy sediments of the Northern Adriatic.

[19] In this study we used a modified form of Athy's [1930] equation to ensure that porosity $\phi(-)$ at "infinite" depth reaches the fixed minimum value $\phi_{b}$ of 0.35 [cf.
Boudreau and Bennett, 1999]. Our parameterized exponential porosity equation is:

$$
\phi=\phi_{0} e^{-c z}+\phi_{b}
$$

where $z$ is depth below the surface $(\mathrm{m}), \phi_{0}+\phi_{b}$ is the porosity (-) at the surface $(z=0)$, c is a constant $(-)$, and $\phi_{b}$ is the porosity (-) at infinite depth. The parameter values and their standard deviations used in our calculations are based on four sediment cores, CM 43, CSS 12, PAL 8, and PAL 77, whose locations are given in Figure 2. The parameter settings are listed in Table 1. Figure 7 shows porosity profiles of the four cores, together with the envelope of simulated porosity profiles based on the parameter settings of Table 1 .

[20] The conversion from bulk volume (thickness $\times$ area) to net sediment mass was carried out as follows. The mean porosity $\bar{\phi}_{i}(-)$ of a sediment column with thickness $d_{i}(\mathrm{~m})$ is given by:

$$
\bar{\phi}_{i}=\frac{1}{d_{i}} \int_{z_{T}}^{z_{B}}\left(\phi_{0} e^{-c z}+\phi_{b}\right) d z
$$

[21] The geostatistical estimate of sediment mass $\tilde{M}$ (Gt) of a lithosome is the sum of the sediment masses of the grid cells with $d_{I}>0$, which for $N$ cells is given by:

$$
\tilde{M}=\rho A \sum_{i=1}^{N}\left(1-\bar{\phi}_{i}\right) d_{i}
$$

where sediment density $(\rho)$ is assumed to be $2.65 \mathrm{Gt} \mathrm{km}^{-3}$, and the area of one grid cell, $A=9 \mathrm{~km}^{2}$.

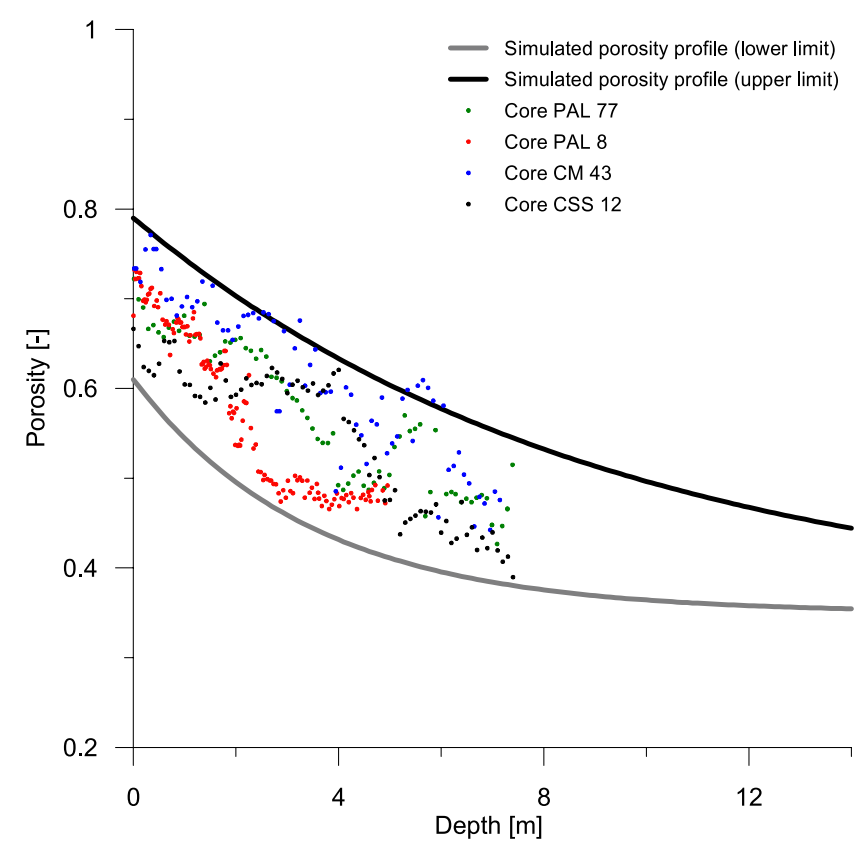

Figure 7. Parameterization of the porosity-depth relation in Adriatic shelf sediments. The envelope of porosity-depth profiles covers mean parameter values \pm three standard deviations. 


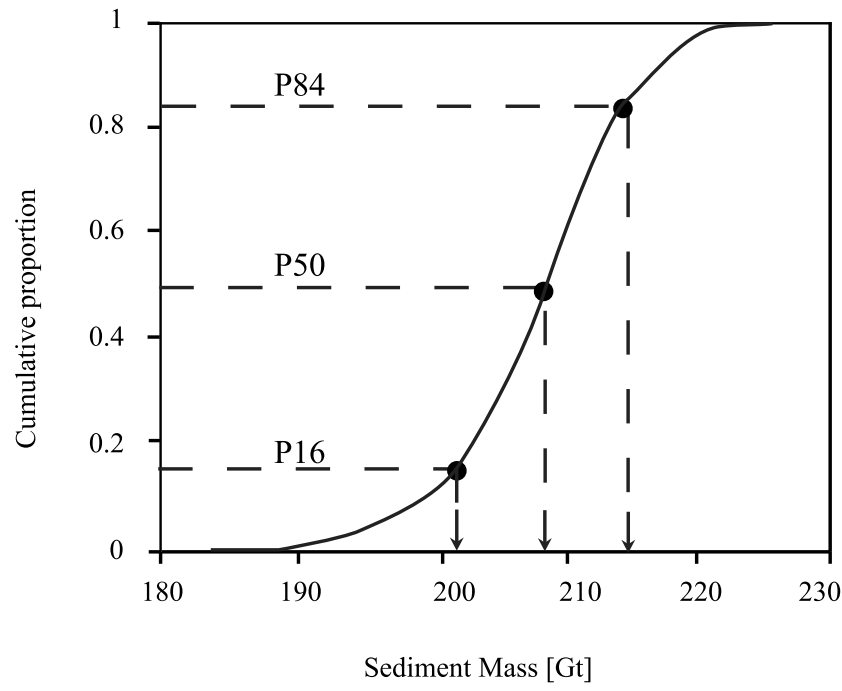

Figure 8. Derivation of $\mu$ and $\sigma$ from cumulative distribution function of sediment mass illustrated for HST1 lithosome.

\subsection{Uncertainty Estimation of Sediment Mass}

[22] The sediment-mass estimation procedure outlined above was carried out 10.000 times for each shelf lithosome. Each geostatistical estimate of shelf mass $(\tilde{M})$ was based on a set of 1000 randomly selected control points, in conjunction with a stochastic realization of the three parameter set $\left(V_{s}, c, \phi_{0}\right)$. For each lithosome, the results of the stochastic simulations were summarized as follows. The representative value of the shelf sediment mass is the median (50th percentile) of 10.000 realizations (Figure 8):

$$
\mu_{\text {shelf }}=\tilde{M}_{50}
$$

[23] The absolute uncertainty (or standard deviation, i.e., the $68 \%$ confidence interval) is derived from the difference between the 16th and the 84 th percentile of the shelf mass distribution:

$$
\sigma_{\text {shelf }}=\frac{\left(\tilde{M}_{84}-\tilde{M}_{16}\right)}{2}
$$

[24] The fractional uncertainties derived from stochastic simulation of sediment masses on the shelf are in the range of $\sim 10 \%$.

\subsection{Deposits in the Po Delta and MAD}

[25] Mass calculations of the onshore deposits and the deposits in the MAD followed largely the same method with a few adaptations. The volumes of sediment deposited in the onshore part of the Po Delta (TST-3, HST-1, and HST-2) were estimated from stratigraphic profiles. The volumes of offshore deposits in the MAD (TST-2, TST-3, and HST-1) were estimated from accumulation rates measured in sediment cores. These thicknesses were interpolated to construct isopach maps in $(x, y, z)$, where $x, y$ are the spatial coordinates and $z$ is the depth of the bounding surface. For the onshore deltaic deposits, we adopted a porosity of about 0.50 near the surface, declining with depth to about 0.25 because of compaction. The porosity profile of deposits in the MAD was assumed to be identical to that of the shelf deposits (Table 1).

[26] The MAD deposits contribute $\sim 15 \%$ to the total sediment mass of the TST- 2 and TST- 3 units, and only $2 \%$ to the total sediment mass of the HST-1 unit (Table 2). Data coverage in the MAD is poor; we therefore adopted a fractional uncertainty of $40 \%$ for the sediment-mass estimates of these units. It should be noted that this somewhat arbitrary choice is not critical to our results. If we alter the fractional uncertainties of the sediment masses in the MAD to for instance $30 \%$ or $50 \%$, absolute uncertainties of the total sediment mass in the TST-2 and TST- 3 lithosomes change by no more than a few percent, and the change in absolute uncertainty of the HST-1 mass is negligible.

\section{Results}

\subsection{Spatial Distribution of Sediment Thickness}

[27] The results of the stochastic analysis are presented in Figures 9a, 9b, 9c, 9d, and 9e which show the integrated thickness maps of the five lithosomes in the Northern Adriatic Basin. Figures $9 \mathrm{a}$ and $9 \mathrm{~b}$ present the thickness maps (m) of the two HST lithosomes (HST-1 and HST-2). Figures $9 \mathrm{c}, 9 \mathrm{~d}$, and $9 \mathrm{e}$ present the thickness maps $(\mathrm{m})$ of the three TST lithosomes (TST-1, TST-2 and TST-3).

\subsection{Total Sediment Mass per Lithosome}

[28] The sediment mass of an entire lithosome $\left(M_{a}\right)$ and its uncertainty $\left(\delta M_{a}\right)$ are obtained as follows [Taylor, 1982]:

$$
\begin{gathered}
M_{a}=\mu_{\text {delta }}+\mu_{\text {shelf }}+\mu_{M A D} \\
\delta M_{a}=\sqrt{\left(\sigma_{\text {delta }}\right)^{2}+\left(\sigma_{\text {shelf }}+\sigma_{M A D}\right)^{2}}
\end{gathered}
$$

[29] Note that the uncertainties associated with the sediment masses of the shelf and MAD deposits are not independent, because they are based on the same parame-

\begin{tabular}{|c|c|c|c|c|c|c|c|c|}
\hline \multirow[b]{2}{*}{ Lithosome } & \multicolumn{2}{|c|}{ Delta } & \multicolumn{2}{|c|}{ Shelf } & \multicolumn{2}{|c|}{ MAD } & \multicolumn{2}{|c|}{ Total } \\
\hline & $\mu(\mathrm{Gt})$ & $\sigma(\mathrm{Gt})$ & $\mu(\mathrm{Gt})$ & $\sigma(\mathrm{Gt})$ & $\mu(\mathrm{Gt})$ & $\sigma(\mathrm{Gt})$ & $\mu(\mathrm{Gt})$ & $\sigma(\mathrm{Gt})$ \\
\hline HST-2 & 2 & 1 & 17 & 2 & Negligible & Negligible & 18 & 2 \\
\hline HST-1 & 14 & 7 & 222 & 26 & 4 & 1 & 236 & 28 \\
\hline TST-3 & 5 & 2 & 177 & 27 & 30 & 12 & 212 & 40 \\
\hline TST-2 & Negligible & Negligible & 98 & 8 & 19 & 8 & 116 & 16 \\
\hline TST-1 & Negligible & Negligible & 37 & 4 & 121 & 18 & 158 & 22 \\
\hline
\end{tabular}
terization of seismic velocity and porosity. The uncertainties associated with the sediment masses of the onshore Po Delta

Table 2. Sediment Masses ${ }^{a}$

${ }^{\mathrm{a}}$ In Ma. 

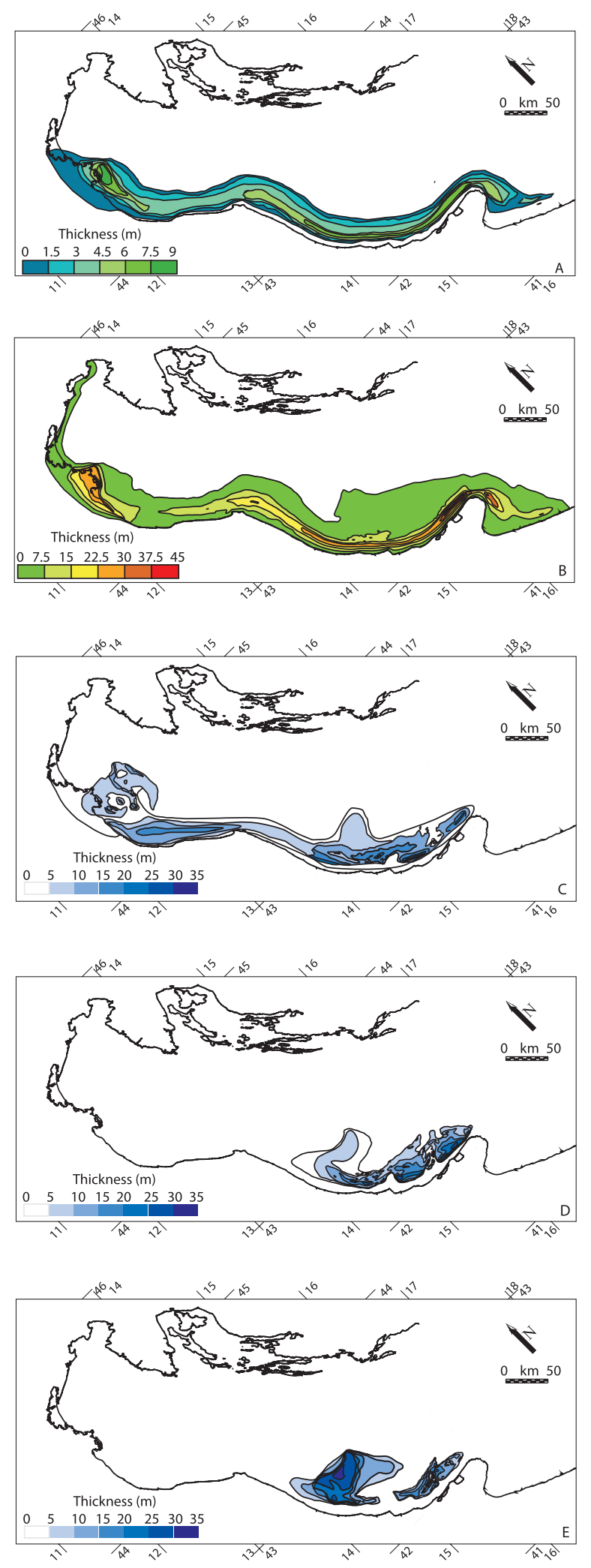

Figure 9. Isopach maps $(\mathrm{m})$ resulting from the stochastic analysis for (a) HST-2, (b) HST-1, (c) TST-3, (d) TST-2, and (e) TST-1. deposits are assumed to be uncorrelated to $\sigma_{\text {shelf }}$ and $\sigma_{M A D}$. This leads to the specific form of equation (10). Fractional uncertainties of the total sediment mass are in the range of $10 \%$ to $20 \%$ (Table 2 ).

\subsection{Basin-Wide Mass Accumulation Rates}

[30] The ages of the bounding surfaces of the seismicstratigraphic units were estimated from ${ }^{14} \mathrm{C}$ measurements. On the basis of the inferences of Lowe et al. [2007], we assigned a fractional uncertainty of $3 \%$ to the age estimates of the bounding surfaces of the Adriatic units, with the exception of the boundary between the HST-1 and HST-2 units, to which we assigned a fractional error of $10 \%$ (Table 3 ). These age assignments $(a)$ and their absolute uncertainties $(\delta a)$ were converted into estimates of the duration of the time slices corresponding to the five lithosomes $(\tau)$ with associated absolute uncertainties $(\delta \tau)$ by means of rootsum-squares (RSS) approximation [Taylor, 1982] under the assumption of uncorrelated errors (Table 3 ).

[31] We calculated the basin-wide mean mass accumulation rate $\left(S_{a}\right)$ for each lithosome as follows:

$$
S_{a}=M_{a} / \tau
$$

[32] Its fractional uncertainty may be obtained by RSS approximation, because uncertainties in mass and duration are uncorrelated:

$$
\frac{\delta S_{a}}{S_{a}}=\sqrt{\left(\frac{\delta M_{a}}{M_{a}}\right)^{2}+\left(\frac{\delta \tau}{\tau}\right)^{2}}
$$

[33] In the above equations, $S_{a}$ is the estimated mass accumulation rate $\left(\mathrm{Gt} \mathrm{ka}^{-1}\right)$ of each lithosome and $\delta S_{a}$ $\left(\mathrm{Gt} \mathrm{ka}^{-1}\right)$ is the associated absolute uncertainty. Relative uncertainties of basin-wide mass accumulation rates are in the order of $\sim 20 \%$ (Table 3 ).

\section{Interpretation and Discussion}

\subsection{Statistical Test}

[34] An adaptation of the well-known Z-test [e.g., Taylor, 1982; Davis, 2002] was used to examine if net basin-wide mass accumulation rates are likely to have varied between time slices. The test was modified to enable a pair-wise comparison of rates (see Appendix A for derivation of test statistic). Strictly speaking, the five mass accumulation rates constitute a time series, which means that they may be serially correlated. However, since we are only assessing the probability that the five estimates are equal, their time order, and consequently, the presence or absence of serial correlation, is irrelevant.

[35] The null hypothesis (equality of two mass accumulation rates) is considered acceptable if its probability exceeds a significance level $\alpha$, which was set at 0.1 (this represents the risk of erroneously rejecting the null hypothesis). The results of applying the $Z$-test to the five mass accumulation rates $\left(H_{0}: S_{a}(i)=S_{a}(j)\right.$, for $\left.i \neq j\right)$ are given in Table 4. The conclusion from this test is that the stratigraphic record does not show evidence of significant variations in basin-wide mass accumulation rates between the five time slices, because the variation is indistinguishable from random error. 
Table 3. Estimated Ages of Bounding Surfaces and Durations of Time Slices

\begin{tabular}{|c|c|c|c|c|c|c|c|}
\hline Bounding Surface & $\begin{array}{c}a \\
(\mathrm{ka})\end{array}$ & $\begin{array}{r}\delta a \\
(\mathrm{ka})\end{array}$ & Lithosome & $\begin{array}{c}\text { Duration of } \\
\text { Time Slices } \tau \\
\text { (ka) }\end{array}$ & $\begin{array}{r}\delta \tau \\
(\mathrm{ka}) \\
\end{array}$ & $\begin{array}{l}\text { Net Accumulation } \\
\text { Rates } S_{a} \\
\left(\mathrm{Gt} \mathrm{ka}^{-1}\right) \\
\end{array}$ & $\begin{array}{c}\delta S_{a} \\
\left(\mathrm{Gt} \mathrm{ka}^{-1}\right) \\
\end{array}$ \\
\hline HST-2/HST-1 & 0.4 & 0.04 & HST-2 & 0.4 & 0.04 & 45 & 7 \\
\hline HST-1/TST-3 (MFS) & 5.5 & 0.17 & HST-1 & 5.1 & 0.17 & 46 & 6 \\
\hline TST-3/TST-2 & 11.3 & 0.34 & TST-3 & 5.8 & 0.38 & 37 & 7 \\
\hline TST-2/TST-1 & 14.8 & 0.44 & TST-2 & 3.5 & 0.56 & 33 & 7 \\
\hline TST-1/LST (MRS) & 19.0 & 0.57 & TST-1 & 4.2 & 0.72 & 38 & 8 \\
\hline
\end{tabular}

[36] Calculation of long-term averages of $S_{a}$, representative of the entire HST and TST, involves the total sediment masses in the two systems tracts as well as their total durations, which reduces their fractional uncertainties (Table 5). The resulting estimates accentuate the difference between net accumulation rates of the TST and HST lithosomes. Application of the $Z$-test to these two long-term average rates gives a probability of 0.11 that the two are equal, which is slightly above the significance level. This result shows that equality of the two mean rates is possible but not very likely. Similar $Z$-tests, in which accumulation rates of individual lithosomes from one systems tract were compared to the average accumulation rate of the other systems tract, failed to reveal significant differences. The grand mean rate of net basinwide mass accumulation in the Northern Adriatic over the past $19 \mathrm{ka}$ is equal to $39 \pm 3 \mathrm{Gt} \mathrm{ka}^{-1}$ (Table 5).

\subsection{Relation to Sediment Supply}

[37] The result of our data analysis refers to the preserved part of the geological record of the Northern Adriatic Basin, i.e., to the net basin-wide accumulation rates within a series of lithosomes. Basin-wide correlation of the surfaces that separate these lithosomes was made possible by the fact that most of them are (at least locally) marked by unconformities. This applies to the lower bounding surface of all three TST units [Trincardi et al., 1994]. In the case of unconformity-bounded units, the relation between net basin-wide mass accumulation rates (MARs) extracted from the stratigraphic record and rates of sediment supply is obscured by intrabasinal erosion and redistribution of sediments, which are particularly common on geological timescales, because the boundary conditions of sediment dispersal systems change because of eustatic and climatic variations [Sadler, 1981; Sommerfield, 2006; Jerolmack and Sadler, 2007]. Other surfaces, such as the MFS, which separates the upper TST from the lower HST unit, and the boundary between the lower and upper HST units, are conformable. Recycling of sediment across conformable bounding surfaces is likely to be insignificant relative to the uncertainty of our estimates.

[38] If a lithosome in a "closed" sedimentary basin is bounded by conformable (nonerosional) surfaces, the quantity of sediments preserved within that unit is expected to be

Table 4. Pairwise Comparison of Net Accumulation Rates $S_{a}$ in Terms of Probabilities Under the Null Hypothesis (Equality of Estimates)

\begin{tabular}{lcccc}
\hline & HST-2 & HST-1 & TST-3 & TST-2 \\
\hline HST-1 & 0.89 & & & \\
TST-3 & 0.40 & 0.31 & & \\
TST-2 & 0.24 & 0.17 & 0.74 & \\
TST-1 & 0.50 & 0.41 & 0.92 & 0.68 \\
\hline
\end{tabular}

equal (within the limits of uncertainty) to the quantity of sediment supplied during the time interval corresponding to that unit. This applies to unit $\mathrm{u}_{1}$ (Figure 10a). In Figure 10b, unit $\mathrm{u}_{2}$ is bounded on top by an erosional surface, which indicates that some of the material originally deposited in unit $\mathrm{u}_{2}$ has been recycled into unit $\mathrm{u}_{3}$. Hence, if we would base our MAR calculations solely on unit $u_{3}$, we would overestimate the amount of sediment supplied during the time interval corresponding to that unit. Likewise, the MAR over the time interval corresponding to unit $\mathrm{u}_{2}$ would be underestimated. However, the two units $\mathrm{u}_{2}$ and $\mathrm{u}_{3}$ together will contain the correct quantity of sediments supplied in the combined time intervals corresponding to both units, which indicates that it should be possible to equate the average MAR over the combined duration of the two units to the average rate of sediment supply. Figure 10c illustrates the effects of two superimposed erosional surfaces. In this case, we have one unit that will be underestimated $\left(\mathrm{u}_{2}\right)$, one that will be overestimated $\left(\mathrm{u}_{4}\right)$, and one unit that may contain either more or less sediment than the quantity actually supplied in the corresponding time interval $\left(\mathrm{u}_{3}\right)$, depending on the difference between the quantities recycled across the bounding surfaces. Again, a MAR that is representative of sediment supply may be calculated over the combined interval of the three units.

[39] Hence, from a (long-term) sequence-stratigraphic perspective, a mismatch between rates of sediment supply and mass accumulation is expected in the case of unconformitybounded units. This implies that only our calculations pertaining to the two HST units (and the HST as a whole) can be directly interpreted in terms of basin-wide average rates of sediment supply, because these units are bounded by conformities. The same applies to the long-term average MARs of the TST and the HST + TST reported in Table 5, because addition of sediment to the TST by reworking, indicated by the fact that the MRS locally coincides with a ravinement surface, is likely to be negligible relative to the uncertainty associated with our estimates.

\subsection{Analysis of the HST-2 Lithosome}

[40] The feasibility of inferring rates of sediment supply from conformity-bounded lithosomes in a "closed" basin is illustrated by a comparison of our reconstruction of the

Table 5. Masses $M_{a}$ and Accumulation Rates $S_{a}$ of the HST, LST, and HST + TST Lithosomes With Their Absolute Uncertainties

\begin{tabular}{lcccc}
\hline Lithosome & $M_{a}(\mathrm{Gt})$ & $\delta M_{a}(\mathrm{Gt})$ & $S_{a}\left(\mathrm{Gt} \mathrm{ka}^{-1}\right)$ & $\delta S_{a}\left(\mathrm{Gt} \mathrm{ka}^{-1}\right)$ \\
\hline HST & 254 & 28 & 46 & 5 \\
TST & 486 & 48 & 36 & 4 \\
HST + TST & 740 & 56 & 39 & 3 \\
\hline
\end{tabular}




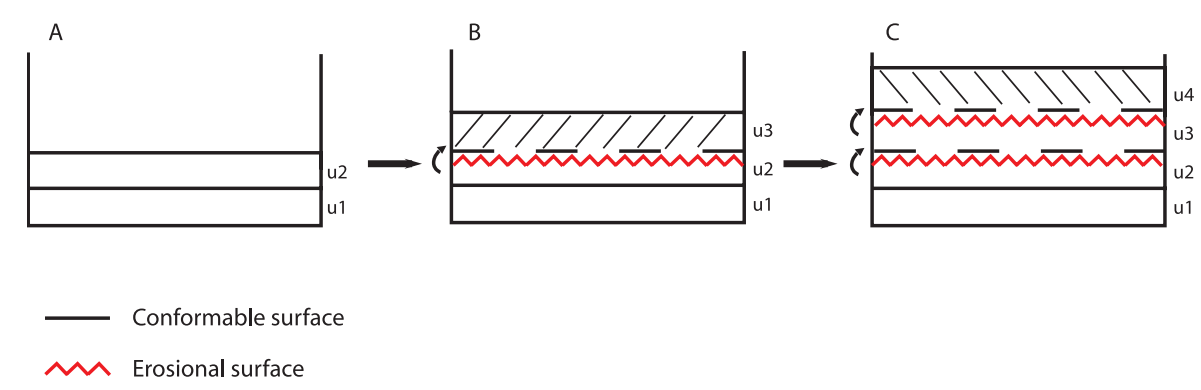

Figure 10. (a, b, c) Effects of sediment recycling on mass preservation in the stratigraphic record.

uppermost lithosome (HST-2 unit) with data on present-day MARs presented by Frignani et al. [2005]. They calculated MARs over the entire Northwest Adriatic shelf on the basis of activity-depth profiles of excess ${ }^{210} \mathrm{~Pb}$ supported by ${ }^{137} \mathrm{Cs}$ depth distributions. The spatial distribution pattern and absolute values of these MARs are in broad agreement with inferences from a number of recent studies on short-term deposition rates [Wheatcroft et al., 2006; Palinkas and Nittrouer, 2007]. The isotopes ${ }^{210} \mathrm{~Pb}$ and ${ }^{137} \mathrm{Cs}$ have halflives of 23 and 30 years, respectively. Therefore, calculations based on these isotopes reflect decadal averages. On the basis of the data of Frignani et al. [2005], the total quantity of sediments accumulating on the Northern Adriatic shelf is estimated to be $\sim 43 \mathrm{Mt} \mathrm{a}^{-1}$. This quantity is virtually identical to the independently derived estimate of Syvitski and Kettner [2007], which equals $\sim 42 \mathrm{Mt} \mathrm{a}^{-1}$ and covers essentially the same timescale.

[41] We derived a centennial average of basin-wide MAR from the analysis of the HST-2 lithosome (0.4-0.0 ka B.P.) that occupies the Adriatic shelf and part of the onshore Po Delta. The modern Po Delta has advanced rapidly since 1604 A.D. because of canalizations of the delta tributaries [Nelson, 1970]. We derived the total sediment mass of the HST-2 lithosome seaward of the $\sim 1600$ A.D. coastline (Figure 1) by means of the stochastic analysis as described above. The basin-wide MAR derived from this portion of the HST-2 lithosome, which reflects a centennial average, equals $43 \pm 7 \mathrm{Mt} \mathrm{a}^{-1}$. The two basin-wide MARs and the simulated rate of basin-wide sediment supply, which were derived by independent methods, are statistically indistinguishable. Hence, the comparison of three independent estimates of mass accumulation in the conformity-bounded HST-2 lithosome confirms the above principle and demonstrates that the Northern Adriatic Basin is a closed system.

\subsection{Spatial-Temporal Scales of Mass Accumulation Rates}

[42] From a (long-term) sequence-stratigraphic perspective, a possible mismatch between rates of sediment supply and mass accumulation should be minimal in the case of conformity-bounded units. However, formation of shelf stratigraphy is not an instantaneous process. This implies a mismatch between the two rates if time series on which local accumulation rates are based are shorter than the average time involved in displacing river mouth sediments to a more permanent position, the so-called base level. Since the notion of base level is intimately coupled with preservation potential, it is implicitly tied to a specific temporal scale [cf. Sommerfield, 2006]. Jerolmack and Sadler [2007] discuss sediment accumulation rates in relation to the morphological evolution of continental shelves and coastal plains in an attempt to estimate the timescale at which transience gives way to persistence. On the basis of their findings the authors concluded that persistent landscapes begin to form at $10^{2}$ to $10^{3}$ years and are complete by $10^{4}$ to $10^{5}$ years.

[43] We can clearly illustrate this concept by a comparison of the reconstruction of the lower HST lithosome (HST-1) with the uppermost lithosome (HST-2), and by a comparison of the uppermost lithosome (HST-2) with data on present-day MARs presented by Frignani et al. [2005] on the basis of the isotopes ${ }^{210} \mathrm{~Pb}$ and ${ }^{137} \mathrm{Cs}$, which reflect decadal average MARs.

[44] Figure 11a depicts the millennial averaged mass fluxes $\left(\mathrm{g} \mathrm{cm}^{-2} \mathrm{a}^{-1}\right)$ derived from the thickness distribution of the HST-1 lithosome. Figure 11b presents the centennial averaged mass fluxes derived from the thickness distribution of the HST-2 lithosome. Figure $11 \mathrm{c}$ presents the corresponding decadal averages calculated from the data of Frignani et al. [2005].

[45] The spatial variation of mass fluxes brings out systematic differences between decadal, centennial and millennial averages. The decadal average mass flux (Figure 11a) shows that sediments tend to accumulate near the coast and especially off the river mouths of the Po Delta distributaries. On centennial timescales (Figure 11b), sediments are reworked and displaced basinward (cross-shore) along most of the Adriatic coast. In addition, the pattern also shows a net trend of longshore progradation in the most distal part of the lithosome, which reflects the growth of the recent Gargano subaqueous delta (Figure 1) [Cattaneo et al., 2003]. Other features of interest include the area around the modern Po Delta, showing a rapid progradation which started around 1600 A.D. [Correggiari et al., 2001] and the low preservation potential of sediments presently accumulating near the coast. The pattern of millennial average mass fluxes (Figure 11c) is in many ways similar to the centennial average fluxes, albeit without the localized accumulation in front of the modern Po Delta. Hence, much of the sediment which has accumulated over the past decades in the Northern Adriatic is likely to represent a transient stratigraphic record, because the nearsurface sediments have not yet reached their long-term repositories.

\section{Conclusions}

[46] Our quantitative analysis demonstrates that a probabilistic assessment of MARs in a well-documented "closed" basin potentially allows reconstruction of time-averaged 

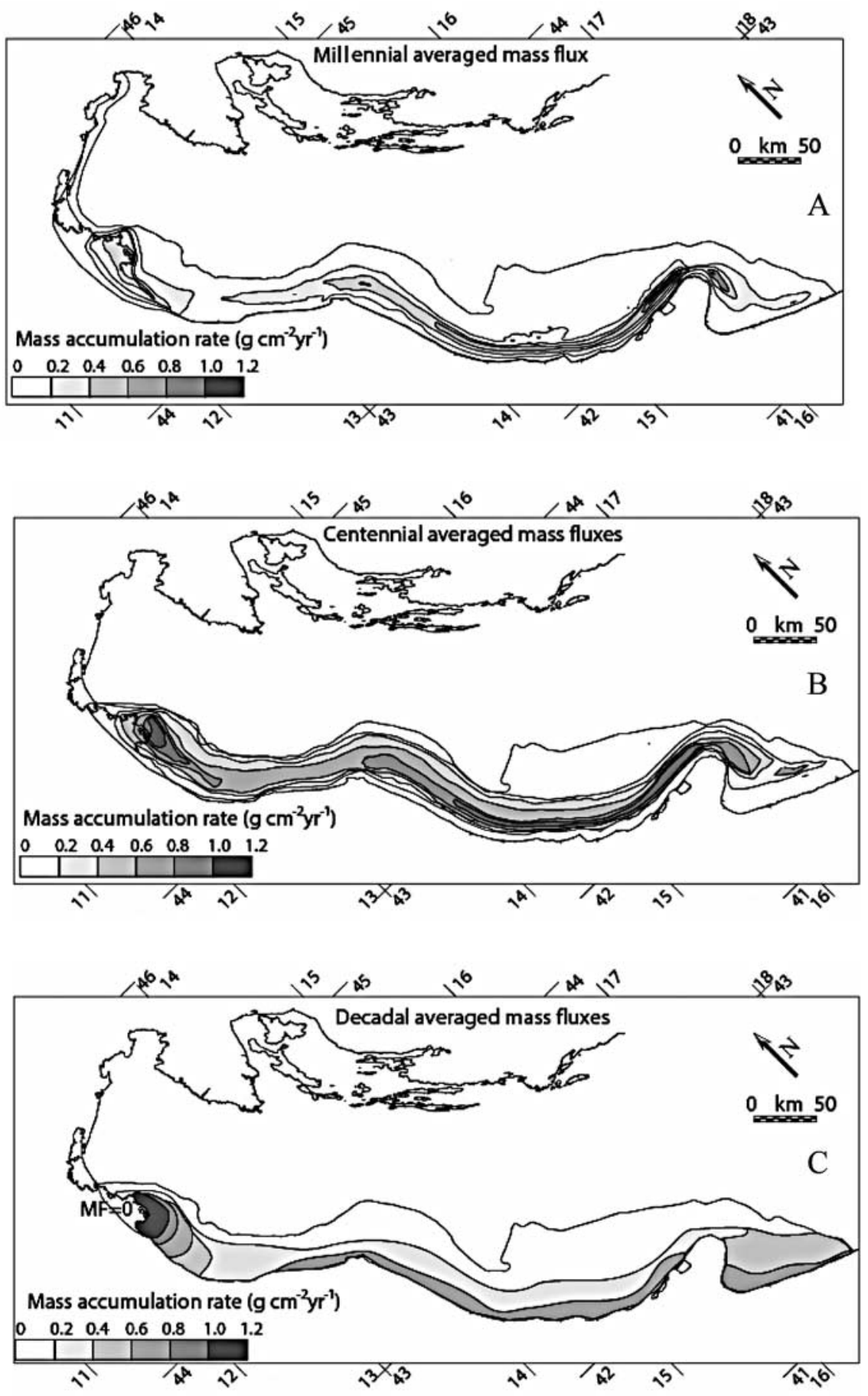

Figure 11. (a) Millennial, (b) centennial, and (c) decadal averaged mass fluxes $\left(\mathrm{g} \mathrm{cm}^{-2} \mathrm{a}^{-1}\right)$.

rates of sediment supply, provided the basin fill can be subdivided into conformity-bounded units.

[47] The data currently at our disposal permit us to adopt this approach for the two youngest lithosomes corresponding to the HST, and possibly for the TST as a whole. Indeed, our estimate of basin-wide MAR from the uppermost lithosome (HST-2) closely matches the independent estimates of Frignani et al. [2005] and Syvitski and Kettner [2007] on the basis of modern (decadal-averaged) rates. By comparing mass accumulation rates on three different timescales we demonstrated a low preservation potential of sediments presently accumulating near the coast. The Late Holocene evolution of the Northern Adriatic mud belt is characterized by a continuous alongshore and cross-shore sediment transport regime. The spatial variation of sediment accumulation rates over different time intervals in the mud belt indicates that the stratigraphic record which has formed during the last century must be considered transient (sensu Jerolmack and Sadler [2007]). The change from transient to persistent 
accumulation patterns seems to occur at the centennial to millennial timescale.

[48] We are unable to reject the null hypothesis that the millennial-scale averages of net basin-wide MARs are equal, although the discrepancy between average MARs of the HST and TST lithosomes suggests that the long-term average rate of sediment supply has increased over the past $19 \mathrm{ka}$. Given the fact that order-of-magnitude variations in rates of fluvial sediment supply to marine basins have been postulated by many authors working in the (Late) Quaternary [Leeder et al., 1998; Blum and Törnqvist, 2000; Meybeck and Vörösmarty, 2005], our results are perhaps perceived as disappointing. But the limitations imposed by our database (and its uncertainties) do not allow us to draw more specific conclusions.

[49] In view of the fractional uncertainties associated with basin-wide net MARs, which are in the range of $20 \%$, our findings could be interpreted in terms of signal attenuation, attributable to the limited time resolution of the stratigraphic record. This problem may be overcome with a significantly improved age model that would enable us to reduce the uncertainty of the duration of the five time slices. Further improvements in estimation of sediment mass from seismics are also possible with better control on porosity profiles, which should allow us to further constrain the stochastic simulations. Further methodological improvements may ultimately lead to the distinction of more time slices within a basin fill. Undoubtedly, high-resolution analyses of basin fills conducted with a vastly improved methodology would demonstrate that variations in rates of mass accumulation also exist in the stratigraphic record. Unfortunately, none of these improvements are by themselves sufficient to aid interpretation of net basin-wide MARs in terms of rates of sediment supply. The main reason for this is recycling of sediments, which causes sediments deposited in a given time interval to be reworked and incorporated into younger units [Einsele, 2000]. In view of the recycling problem, the preferred approach to sediment-supply reconstructions is to subdivide the stratigraphic record into conformity-bounded genetic sequences [Galloway, 1989].

[50] It is clear from the above discussion that there are limits to the information that can be extracted from the stratigraphic record, which indicates that the recycling problem must be tackled in a different way. It is highly likely that the liquid and solid discharges of the rivers bordering the Northern Adriatic Basin have varied both in space and time. Numerical models of water and sediment delivery, such as HydroTrend [Syvitski and Kettner, 2007], could be employed to simulate sediment supply in order to constrain the sediment budget of a "closed" basin such as the Northern Adriatic on the basis of palaeo data derived from proxies and Global Circulation Models. If successful, this approach will lead to a mass balanced model of supply and accumulation, which may shed more light on the dynamics of sediment dispersal, deposition, and recycling on geologically relevant timescales.

\section{Appendix A: $Z$-Test for Equality of Two Quantities With Associated Errors}

[51] Let $x_{1} \pm \delta x_{1}$ and $x_{2} \pm \delta x_{2}$ be two estimated quantities (with associated standard deviations) we wish to test for equality. The fractional errors of the two quantities are defined as $\frac{\delta x_{1}}{\left|x_{1}\right|}$ and $\frac{\delta x_{2}}{\left|x_{2}\right|}$, respectively.

[52] Commonly used tests of equality of means, such as the two-sample $t$-test, cannot be applied in this case, because these require specification of sample sizes [Davis, 2002]. An alternative is provided by the familiar $Z$-test, which relates normally distributed variables to the standard normal distribution $N(0,1)$ by applying the transformation:

$$
Z=\frac{X-\mu}{\sigma}
$$

where $Z$ is a standard normal deviate, i.e., a number drawn from $N(0,1), X$ is the quantity of interest, assumed to be distributed as $N(\mu, \sigma), \mu$ is the population mean, and $\sigma$ is the population standard deviation [Taylor, 1982; Davis, 2002].

[53] Our adaptation of the Z-test is based on evaluation of the ratio of the two estimated quantities. Because the ratio of two identical numbers with associated normally distributed errors follows a Lognormal distribution, we take the logarithm of the ratio, which leads to the following log ratio test.

[54] The quantity of interest is defined as $y=\ln q$, where $q=$ $\frac{x_{1}}{x_{2}}$. If the errors $\delta x_{1}$ and $\delta x_{2}$ are uncorrelated, the fractional error associated with $q$ equals: $\frac{\delta q}{|q|}=\sqrt{\left(\frac{\delta x_{1}}{\left|x_{1}\right|}\right)^{2}+\left(\frac{\delta x_{2}}{\left|x_{2}\right|}\right)^{2}}$.

[55] The absolute error associated with $y$ is given by: $\delta y=$ $\left(\frac{d y}{d q}\right) \delta q$.

[56] Because $\frac{d y}{d q}=\frac{d \ln q}{d q}=\frac{1}{q}$, we obtain an absolute error $\delta y=\frac{\delta q}{|q|}$, and it follows that: $\delta y=\sqrt{\left(\frac{\delta x_{1}}{\left|x_{1}\right|}\right)^{2}+\left(\frac{\delta x_{2}}{\left|x_{2}\right|}\right)^{2}}$.

[57] The test statistic $Z$ is then defined as:

$$
Z=\frac{-|y|}{\delta y}
$$

[58] We can test the hypothesis $\mathrm{H}_{0}: x_{1}=x_{2}$ (which is equivalent to $Z=0$ ) by evaluation of the integral of $N(0,1): P\left(H_{0}\right)=2 \int_{-\infty}^{Z} \frac{1}{\sqrt{2 \pi}} e^{-x^{2} / 2} d x$, which gives the two-sided probability $P$ under the null hypothesis. The value of $P\left(H_{0}\right)$ represents the probability of observing a difference greater than or equal to $\left|x_{1}-x_{2}\right|$ if the two are in fact identical.

\section{Notation}

$A$ area of grid cell $\left(\mathrm{km}^{2}\right)$.

$a$ age of bounding surface (ka).

$c$ constant (porosity-depth equation) (nondimensional).

$d$ thickness (m).

HST highstand systems tract (5.5-0.0 ka B.P.).

HST-1 lower HST unit (5.5-0.4 ka B.P.).

HST-2 upper HST unit (0.4-0.0 ka B.P.).

LGM Last Glacial Maximum.

LST lowstand systems tract.

$\tilde{M}$ stochastic realization of sediment mass (Gt).

$M_{a}$ sediment mass of entire lithosome (Gt).

MAD Mid-Adriatic Deep.

MAR mass accumulation rate.

MFS maximum Flooding Surface, separating the TST from the HST (5.5 ka B.P.). 
MRS maximum Regressive Surface, separating the LST from the TST (19.0 ka B.P.).

$S_{a}$ basin-wide mass accumulation rate $\left(\mathrm{Gt} \mathrm{ka}^{-1}\right)$.

$t$ two-way traveltime of seismic signal (ms).

$\tilde{t}$ transformed $t$ value (ms).

$t_{B} \quad t$ from surface to bottom of lithosome (s).

$t_{T} \quad t$ from surface to top of lithosome (s).

TST transgressive Systems Tract (19.0-5.5 ka B.P.).

TST-1 lower TST unit (19.0-14.8 ka B.P.).

TST-2 middle TST unit (14.8-11.3 ka B.P.).

TST-3 upper TST unit (11.3-5.5 ka B.P.).

$V_{s}$ seismic velocity $\left(\mathrm{m} \mathrm{s}^{-1}\right)$.

$z$ depth below surface $(\mathrm{m})$.

$z_{T}$ depth of top lithosome (m).

$z_{B}$ depth of bottom lithosome (m).

$\delta a$ absolute uncertainty of $a(\mathrm{ka})$.

$\delta M_{a}$ absolute uncertainty of $M_{a}(\mathrm{Gt})$.

$\delta S_{a}$ absolute uncertainty of $S_{a}\left(\mathrm{Gt} \mathrm{ka}^{-1}\right)$.

$\delta \tau$ absolute uncertainty of $\tau(\mathrm{ka})$.

$\varepsilon$ constant (geostatistical interpolation) (ms).

$\mu_{\text {delta }}$ median sediment mass of delta deposits (Gt).

$\mu_{M A D}$ median sediment mass of MAD deposits (Gt).

$\mu_{\text {shelf }}$ median sediment mass of shelf deposits (Gt).

$\rho$ sediment (grain) density $\left(\mathrm{Gt} \mathrm{km}^{-3}\right)$.

$\sigma_{\text {shelf }}$ absolute uncertainty of $\mu_{\text {shelf }}(\mathrm{Gt})$.

$\sigma_{\text {delta }}$ absolute uncertainty of $\mu_{\text {delta }}(\mathrm{Gt})$.

$\sigma_{M A D}$ absolute uncertainty of $\mu_{M A D}(\mathrm{Gt})$.

$\tau$ duration of time slice (ka).

$\phi$ porosity at depth $z$ (nondimensional).

$\bar{\phi}$ vertically averaged porosity (nondimensional).

$\phi_{b}$ porosity at infinite depth (nondimensional).

$\phi_{0}$ surface porosity (nondimensional).

[59] Acknowledgments. The Research Council for Earth and Life Sciences (ALW) supported M.B.B. with financial aid from the Netherlands Organization for Scientific Research (NWO), under contract 813.03.005. G.J.W. enjoyed partial financial support from the European Union under the Eurostrataform research program (contract EVK3-CT-2002-00079). M.B.B. thanks Domenico Ridente for help and support at the CNR-ISMAR in Bologna. We owe a special thanks to Leonardo Langone for tracking down the porosity data. The thoughtful comments on earlier versions of this paper by JGR reviewers John Tipper, Maria Teresa Pareschi, an anonymous reviewer, and associate editor Greg Hancock are gratefully acknowledged.

\section{References}

Agarwal, R. G., D. C. Gardner, S. W. Kleinsteiber, and D. D. Fussell (1999), Analyzing well production data using combined-type-curve and decline-curve analysis concepts, SPE Reservoir Eval. Eng., 2, 478-486, doi:10.2118/57916-PA.

Alvisi, F., and M. Frignani (1996), ${ }^{210} \mathrm{~Pb}$-derived sediment accumulation rates for the central Adriatic Sea and crater lakes Albano and Nemi (central Italy), Mem. Ist. Ital. Idrobiol. Dott. Marco de Marchi, 55, $303-320$.

Amorosi, A., and S. Milli (2001), Late Quaternary depositional architecture of Po and Tevere river deltas (Italy) and worldwide comparison with coeval deltaic successions, Sediment. Geol., 144, 357-375, doi:10.1016/S0037-0738(01)00129-4.

Amorosi, A., M. L. Colalongo, F. Fusco, G. Pasini, and F. Fiorini (1999), Glacio-eustatic control of continental-shallow marine cyclicity from late Quaternary deposits of the Southeastern Po plain, Northern Italy, Quat. Res., 52, 1-13, doi:10.1006/qres.1999.2049.

Amorosi, A., M. C. Centineo, M. L. Colalongo, G. Pasini, G. Sarti, and S. C. Vaiani (2003), Facies architecture and latest Pleistocene-Holocene Depositional history of the Po Delta (Comacchio Area), Italy, J. Geol., 111, 39-56, doi:10.1086/344577.

Amorosi, A., M. C. Centineo, M. L. Colalongo, and F. Fiorini (2005), Milennial-scale depositional cycles from the Holocene of the Po Plain, Italy, Mar. Geol., 222-223, 7-18, doi:10.1016/j.margeo.2005.06.041.

Asioli, A. (1996), High resolution foraminifera biostratigraphy in the central Adriatic Basin during the last deglaciation: A contribution to the
PALICLAS project, Mem. Ist. Ital. Idrobiol. Dott. Marco de Marchi, $55,197-217$.

Asioli, A., F. Trincardi, J. J. Lowe, D. Ariztegui, L. Langone, and F. Oldfield (2001), Sub-millennial scale climate oscillations in the central Adriatic during the late-glacial: Palaeoceanographic implications, Quat. Sci. Rev., 20, 1202-1221, doi:10.1016/S0277-3791(00)00147-5.

Athy, L. F. (1930), Density, porosity, and compaction of sedimentary rocks, AAPG Bull., 14, 1-24.

Bahr, D. B., E. W. Hutton, J. P. M. Syvitski, and L. F. Pratson (2001), Exponential approximations to compacted sediment profiles, Comput. Geosci., 27, 691-700, doi:10.1016/S0098-3004(00)00140-0.

Bartetzko, A., and A. Kopf (2007), The relationship of undrained shear strength and porosity with depth in shallow $(<50 \mathrm{~m})$ marine sediments, Sediment. Geol., 196, 235-249.

Bayer, U., and A. Wetzel (1989), Compactional behavior of fine-grained sediments - Examples from Deep Sea Drilling Project Cores, Geol. Rundsch., 78, 807-819, doi:10.1007/BF01829324.

Bertrand, A., and C. MacBeth (2003), Seawater velocity variations and realtime reservoir monitoring, Lead. Edge (Tulsa Okla.), 22, 351-355, doi:10.1190/1.1572089.

Blum, M., and T. Törnqvist (2000), Fluvial responses to climate and sealevel change: A review and look forward, Sedimentology, 47, 2-48, doi:10.1046/j.1365-3091.2000.00008.x.

Boudreau, B. P., and R. H. Bennett (1999), New rheological and porosity equations for steady-state compaction, Am. J. Sci., 299, 517-528, doi:10.2475/ajs.299.7-9.517.

Bruckmann, W. (1989), Typische Akkretionsablaufe mariner Sedimente und ihre Modifikation in einem rezenten Akkretionskeil (Barbados Ridge), Tubinger Geowiss. Arb., Reihe A, 5, 1-135.

Carminati, E., and G. Martinelli (2002), Subsidence rates in the Po plain, northern Italy: The relative impact of natural and anthropogenic causation, Eng. Geol., 66, 241-255, doi:10.1016/S0013-7952(02)00031-5.

Cattaneo, A., and F. Trincardi (1999), The late Quaternary transgressive record in the Adriatic epicontinental sea: Basin widening and facies partitioning, in Isolated Shallow Marine Sand Bodies: Sequence Stratigraphic Analysis and Sedimentologic Interpretation, edited by K. M. Bergman and J. W. Snedden, Spec. Publ., 64, 127-146, Soc. for Sediment. Geol., Tulsa, Okla.

Cattaneo, A., A. M. Correggiari, L. Langone, and F. Trincardi (2003), The late-Holocene Gargano subaqueous delta, Adriatic shelf: Sediment pathways and supply fluctuations, Mar. Geol., 193, 61-91, doi:10.1016/ S0025-3227(02)00614-X.

Correggiari, A. M., F. Trincardi, L. Langone, and M. Roveri (2001), Styles and failures in the late Holocene highstand prodelta wedges on the Adriatic shelf, J. Sediment. Res., Sect. B, 71, 218-236, doi:10.1306/ 042800710218.

Correggiari, A. M., A. Cattaneo, and F. Trincardi (2005), The modern Po Delta system: Lobe switching and asymmetric prodelta growth, Mar. Geol., 222-223, 49-74, doi:10.1016/j.margeo.2005.06.039.

Davis, J. C. (2002), Statistics and Data Analysis in Geology, 3rd ed., 638 pp., John Wiley, New York.

Einsele, G. (2000), Sedimentary Basins: Evolution, Facies, and Sediment Budget, 792 pp., Springer, Berlin.

Einsele, G., and M. Hinderer (1998), Quantifying denudation and sedimentaccumulation systems (open and closed lakes): Basic concepts and first results, Palaeogeogr. Palaeoclimatol. Palaeoecol., 140, 7-21, doi:10.1016/S0031-0182(98)00041-8.

Farabegoli, E., G. Onorevoli, and C. Bacchiocchi (2004), Numerical simulation of Holocene depositional wedge in the southern Po Plain-northern Adriatic Sea (Italy), Quat. Int., 120, 119-132, doi:10.1016/ j.quaint.2004.01.011.

Favalli, M., and M. T. Pareschi (2004), Digital elevation model construction from structured topographic data: The DEST algorithm, J. Geophys. Res., 109, F04004, doi:10.1029/2004JF000150.

Frignani, M., L. Langone, M. Ravaioli, D. Sorgente, F. Alvisi, and S. Albertazzi (2005), Fine-sediment mass balance in the western Adriatic continental shelf over a century time scale, Mar. Geol., 222-223, 113133, doi:10.1016/j.margeo.2005.06.016.

Galloway, W. E. (1989), Genetic stratigraphic sequences in basin analysis I: Architecture and genesis of flooding-surface bounded depositional units, AAPG Bull., 73, 125-142.

Giles, M. R. (1996), Diagenesis - A Quantitative Perspective, 435 pp., Kluwer Acad., Dordrecht, Netherlands.

Hallet, B., L. Hunter, and J. Bogen (1996), Rates of erosion and sediment evacuation by glaciers: A review of field data and their implications, Global Planet. Change, 12, 213-235, doi:10.1016/0921-8181(95)00021-6.

Hovius, N., and M. Leeder (1998), Clastic sediment supply to basins, Basin Res., 10, 1-5, doi:10.1046/j.1365-2117.1998.00061.x.

Huang, Z., and F. M. Gradstein (1990), Depth-porosity relationship from deep sea sediments, Sci. Drill., 1, 157-162. 
Jerolmack, D. J., and P. Sadler (2007), Transience and persistence in the depositional record of continental margins, J. Geophys. Res., 112, F03S13, doi:10.1029/2006JF000555.

Langone, L., A. Asioli, A. M. Correggiari, and F. Trincardi (1996), Agedepth modelling through the late Quaternary deposits of the central Adriatic Basin, Mem. Ist. Ital. Idrobiol. Dott. Marco de Marchi, 55, $177-196$.

Leeder, M. (1997), Sedimentary basins: Tectonic recorders of sediment discharge from drainage catchments, Earth Surf. Processes Landforms, 22, 229-237, doi:10.1002/(SICI)1096-9837(199703)22:3<229::AIDESP750>3.0.CO;2-F.

Leeder, M. R., T. Harris, and M. J. Kirkby (1998), Sediment supply and climate change: Implications for basin stratigraphy, Basin Res., 10, 7-18.

Lowe, J. J., S. P. E. Blockley, F. Trincardi, A. Asioli, A. Cattaneo, I. P. Matthews, M. Pollard, and S. Wulf (2007), Age modelling of late Quaternary marine sequences in the Adriatic: Towards improved precision and accuracy using volcanic event stratigraphy, Cont. Shelf Res., 27, 560-582, doi:10.1016/j.csr.2005.12.017.

Meybeck, M., and C. J. Vörösmarty (2005), Fluvial filtering of land-toocean fluxes: From natural Holocene variations to Anthropocene, $C$. $R$. Geosci., 337, 107-123, doi:10.1016/j.crte.2004.09.016.

Molnar, P., and P. England (1990), Late Cenozoic uplift of mountain ranges and global climate change: Chicken or egg?, Nature, 346, 29-34, doi:10.1038/346029a0.

Nelson, B. W. (1970), Hydrography, sediment dispersal, and recent historical development of the Po River delta, Italy, in Deltaic Sedimentation, Modern and Ancient, edited by J. P. Morgan, Spec. Publ., 15, 152-184, Soc. for Sediment. Geol., Tulsa, Olka.

Palinkas, C. M., and C. A. Nittrouer (2007), Modern sediment accumulation on the Po shelf, Adriatic Sea, Cont. Shelf Res., 27, 489-505, doi:10.1016/j.csr.2006.11.006.

Paola, C., and J. Swenson (1998), Geometric constraints on composition of sediment derived from erosional landscapes, Basin Res., 10, 37-47, doi:10.1046/j.1365-2117.1998.00055.x.

Park, S. C., H. H. Lee, H. S. Han, G. H. Lee, D. C. Kim, and D. G. Yoo (2000), Evolution of late Quaternary mud deposits and recent sediment budget in the southeastern Yellow Sea, Mar. Geol., 170, 271-278, doi:10.1016/S0025-3227(00)00099-2.

Ridente, D., and F. Trincardi (2005), Pleistocene "muddy" forced-regression deposits on the Adriatic shelf: A comparison with prodelta deposits of the late Holocene highstand mud wedge, Mar. Geol., 222-223, 213-233.

Sadler, P. M. (1981), Sediment accumulation rates and the completeness of stratigraphic sections, J. Geol., 89, 569-584.
Sommerfield, C. K. (2006), On sediment accumulation rates and stratigraphic completeness: Lessons from Holocene ocean margins, Cont. Shelf Res., 26, 2225-2240, doi:10.1016/j.csr.2006.07.015.

Stefani, M., and S. Vincenzi (2005), The interplay of eustasy, climate and human activity in the late Quaternary depositional evolution and sedimentary architecture of the Po Delta system, Mar. Geol., 222-223, 19-48, doi:10.1016/j.margeo.2005.06.029.

Syvitski, J. P. M., and A. J. Kettner (2007), On the flux of water and sediment into the Northern Adriatic Sea, Cont. Shelf Res., 27, 296-308, doi:10.1016/j.csr.2005.08.029.

Taylor, J. R. (1982), An Introduction to Error Analysis: The Study of Uncertainties in Physical Measurements, 270 pp., Univ. Sci. Books, Mill Valley, Calif.

Trincardi, F., A. M. Corregiari, and M. Roveri (1994), Late Quaternary transgressive erosion and deposition in a modern epicontinental shelf: The Adriatic semi-enclosed basin, Geo Mar. Lett., 14, 41-51, doi:10.1007/BF01204470.

Trincardi, F., A. Cattaneo, A. Asioli, A. M. Correggiari, and L. Langone (1996), Stratigraphy of the Late Quaternary deposits in the central Adriatic Basin and the record of short-term climatic events, Mem. Ist. Ital. Idrobiol. Dott. Marco de Marchi, 55, 39-70.

Walling, D. E. (2006), Human impact on land-ocean sediment transfer by the world's rivers, Geomorphology, 79, 192-216, doi:10.1016/j.geomorph. 2006.06.019.

Weltje, G. J., X. D. Meijer, and P. L. de Boer (1998), Stratigraphic inversion of siliciclastic basin fills: A note on the distinction between supply signals resulting from tectonic and climatic forcing, Basin Res., 10, 129153, doi:10.1046/j.1365-2117.1998.00057.x.

Wheatcroft, R. A., A. W. Stevens, L. M. Hunt, and T. M. Milligan (2006), The large-scale distribution and internal geometry of the Fall $2000 \mathrm{Po}$ River flood deposit: Evidence from digital X-radiography, Cont. Shelf Res., 26, 499-516, doi:10.1016/j.csr.2006.01.002.

White, D. A., and H. M. Gehman (1979), Methods of estimating oil and gas resources, AAPG Bull., 63, 2183-2192.

M. B. Brommer, Royal Haskoning, Rightwell House, Peterborough PE3 8DW, UK. (m.brommer@royalhaskoning.com)

F. Trincardi, Istituto per la Geologia Marina, CNR-ISMAR, Via Gobetti 101, I-40129 Bologna, Italy.

G. J. Weltje, Department of Geotechnology, Delft University of Technology, P.O. Box 5048, NL-2600GA, Delft, Netherlands. 